\title{
Multicultural Health Diplomacy: A Proposed Culturally Competent Diplomacy Model for Health Professionals
}

\author{
By Rachel Boveja*
}

\begin{abstract}
Diplomatic skills are essential for international relations and foreign affairs. However, diplomacy can be valuable for other global initiatives, such as public health. In many countries, healthcare has been affected by migration and has impacted individuals from various cultural backgrounds. As perceptions of health vary among cultural groups, so do the health services needed to accommodate those groups. Some healthcare challenges include limitations in communication and cultural literacy. Therefore, it is imperative to review innovative tools being used to accommodate these global health movements. Multicultural Health Diplomacy is a proposed model for the purpose of training health professionals with a set of skills suitable for engaging in transcultural healthcare. Fundamental to health education and healthcare services, these skills can serve as a model to create a healthcare system which supports the diversity and well-being of all individuals. Multicultural Health Diplomacy is inspired from Global Health Diplomacy, which has its foundation in foreign policy. Therefore, using these skills at the community level can also serve as a conduit for bridging ground level healthcare to foreign policy. The purpose of this paper is to review current trends in multicultural health and diplomacy training models used across several industries. The current status of global migration is highlighted to express the need for cultural competency training for health professionals at institutional, organizational, community, and individual levels. In particular, this paper focuses on the use of diplomacy skills in cultural health competency training to aid in the interaction and ongoing relationships between healthcare professionals and the diversity of individuals receiving healthcare services.
\end{abstract}

Keywords: Healthcare diplomacy, Healthcare training, Cultural competency, Multicultural health, Multicultural competency.

\section{Introduction}

\section{Multicultural Health}

Global communities, institutions of higher education, and the workforce are increasingly training individuals to be culturally competent because of the growing diversity in our world. Employers from every sector are looking for individuals who know how to work with diverse individuals and have had diverse experiences (Walsh 2017). Furthermore, Walsh suggests that "[Multicultural] competency in today's marketplace is the difference between success and failure" (Walsh 2017). The health industry is also expanding to identify trends in multicultural health. According to the Royal Australian College of General Practitioners, multicultural health can be defined as

"Multicultural health...reflects how the core principles of multiculturalism operate within the context of general practice, including ensuring that the training of general practitioners has a strong and specific emphasis on

${ }^{*} \mathrm{PhD}$ Candidate \& Associate Instructor, Indiana University, USA. 
building cultural competence and effectiveness, that is, the ability to work competently and effectively in a culturally diverse workplace and in encounters with people from different cultural backgrounds to ensure the delivery of high-quality general practice care".

(The Royal Australian College of General Practitioners 2011)

Understanding multicultural health means unwrapping its complex uses and associated terminology, such as cultural competency. Cultural competency is "...the ability to interact effectively with people of different cultures, and helps to ensure the needs of all community members are addressed". ${ }^{1}$ Similar to other definitions associated with "culture", cultural competency is also complex in its purpose (Cross et al. 1989). Meaning, it is a concept and a behavior, among other things. The process of cultural competency is an ongoing practice for working in any cultural context (Echeverri et al. 2013). Yet, the function lies in preparing individuals with knowledge and skills as well as using cultural competency as a tool for cross-cultural communication. Ultimately, multicultural competency implements equity awareness and evidence-based practices at its core (Echeverri et al. 2013, Cullen and Adams 2012).

\section{Diplomacy}

Diplomacy has often been attributed to Foreign Service and international relations. Different cultures make use of the diplomacy concept, but often have their own rules for engaging in diplomatic behaviors. Still, the overall point of diplomacy is to maintain peaceful relationships (McDaniel et al. 2018). For this reason, diplomacy has been defined as both a concept and an actionable behavior trait involving negotiation. Moreover, Gilboa defines diplomacy as "...international negotiation, to a communication system through which representatives of states and international or global actors, including elected officials, express and defend their interests...it is a channel of contact for clarifying positions, probing for information, and convincing states and other actors to support one's position" (Gilboa 2001). Individuals specializing in diplomacy include diplomats, ambassadors, secretaries of state, and other managers of international relations (McDaniel et al. 2018). These individuals are often intermediaries and mediators between different cultural populations. Publicly, diplomacy is often seen on the world stage at the United Nations General Assembly and the Geneva Convention, both overseeing the signing of peace treatises, among other things (McDaniel et al. 2018). Moreover, diplomacy has a history of monumental accomplishments in the forms of the Treaty of Kadesh by Ancient Kemetic Pharaoh Ramesses II and the Treaty of Versailles, which was signed in 1919 (McDaniel et al. 2018).

\footnotetext{
${ }^{1}$ Center for the Application of Prevention Technologies (CAPT) (2016, November 10). Cultural competence. Substance Abuse and Mental Health Services Administration. Available at: https:// www.samhsa.gov/capt/applying-strategic-prevention/cultural-competence.
} 


\section{Diplomacy Characteristics}

Traditional diplomacy was known to be "highly formal, institutional, and protected by secrecy" (Gilboa 2001). Common diplomacy characteristics include, but are not limited to, "thorough understanding of issues and an appreciation for the culture of the people you are negotiating with". ${ }^{2}$ Some notable skills used to support diplomacy include, "active listening, emotional intelligence, showing empathy, assertiveness, rapport, and politeness". ${ }^{3}$ This list demonstrates the need for diplomacy workers to have a repertoire utilizing both knowledge and skills when interacting with individuals from different cultures. Models and frameworks also exist to train individuals conducting diplomatic work (Betlem 2012). Many frameworks have also been developed to replicate diplomacy and implemented in various industries such as business, health, and the media. ${ }^{4}$ This reflects the use of diplomacy skills in trans occupational settings as well as larger global contexts.

\section{Diplomacy in Healthcare}

Diplomacy can be valuable for other global initiatives, such as healthcare. In many countries, healthcare has been affected by migration and impacted individuals from various cultural backgrounds. As perceptions of health vary among cultural groups, so do the health services needed to accommodate those groups. By nature, any individual or company working with diverse cultures, mindsets, and agendas are taking part in diplomatic work (McDaniel et al. 2018). This is no different for health professionals. Therefore, it is imperative to review innovative tools being used to accommodate these global health movements. In support of this concept, the World Health Organization spearheaded Global Health Diplomacy (GHD). ${ }^{5}$ GHD combines the "disciplines of public health, international affairs, management, law and economics and focuses on negotiations that shape and manage the global policy environment for health".

\section{Problem Statement}

Previous research has determined that diplomacy skills are essential across many industries. Yet, few studies specifically discuss how to incorporate these skills in training ground-level health professionals. With globalization at our helm, health professionals across the world need to learn how to interact effectively with different cultures (Nyatanga 2001). Moreover, many populations are suffering in health as a result of the lack of cultural understanding or adequate communication skills between health professional and patients. In order for health professionals to

\footnotetext{
${ }^{2}$ What are the tools of diplomacy? (2018, October). Secretary of State Government. Available at: https://www.state.gov/discoverdiplomacy/diplomacy101/issues/170614.htm.

${ }^{3}$ Tact and diplomacy: Skills You Need (2018, October). Available at: https://www.skillsyouneed. com/ips/tact-diplomacy.html.

${ }^{4}$ Negotiation Strategies for Doctors - Hospitals (2013, October 21). Harvard Business Review. Available at: https://hbr.org/2013/10/negotiation-strategies-for-doctors-and-hospitals.

${ }^{5}$ Global Health Diplomacy (2018, October). World Health Organization. Available at: http://www. who.int/trade/diplomacy/en/.
} 
receive adequate training in this area, diplomacy models must be modified to include the specific needs of health professional/patient interaction, for the purpose of supporting both sides in cultural health negotiation.

\section{Purpose}

The purpose of this paper is to review current trends in multicultural health and diplomacy training models used across several industries. Additionally, this paper will identify what is missing in these models in order to use best practices for creating a new health diplomacy model. The new model will be framed to assist in training health professionals interacting with patients from different cultural backgrounds.

\section{Research Questions}

The research questions framing this review include: What health diplomacy models currently exist? What trends exist across current models? What is missing in current models? What components are needed to create the new model? Who will this new model ultimately benefit? Where would this new model be most useful? and When would this new model be most useful?

\section{Importance and Scope of the Study}

As part of an exploratory review; current diplomacy models will be reviewed which have been used in different industries. These models will be measured against a core diplomacy skills model. After identifying current models, a new health professional model will be developed which will include recommendations from the literature review concerning current issues in multicultural healthcare. Geographically, all current models will be taken from the United States. The United States models will be used as the foundation because of the country's historically diverse demographic and current affairs across the globe. Thus, these models from the US will provide diplomatic insight into working with different cultural populations.

Development of a new model will complement the changing world by offering essential skills for professionals during these evolving times. A new model will identify key actors, issues, and skills regarding multicultural health and diplomacy. Ultimately, it will add to a literature bank which will be drawn upon in the future to help navigate various health beliefs, traditions, disparities, and treatment plans.

Essentially, this paper will highlight the current status of global migration to express the need for cultural competency training for health professionals at institutional, organizational, community, and individual levels. In particular, this paper will focus on the use of diplomacy skills in cultural health competency training to aid in the interaction and ongoing relationships between healthcare professionals and the diversity of individuals receiving healthcare services. 


\section{Literature Review}

\section{Trends in Multicultural Health}

One of the main issues regarding multicultural health is the lack of true cultural literacy among health professionals (Kleinman and Benson 2006). Multicultural health is a universal phenomenon. Moreover, it is transnational because it exists in every part of the world and transcends borders. Multicultural health is also multilevel and involves intrapersonal, interpersonal, family, community, national, and international components (Kleinman and Benson 2006). Multicultural health can be a concept or a treatment plan depending on which part of the process is being undertaken. Additionally, it connects to several other initiatives involving cultural care such as competency, cultural literacy, intercultural competence, cross-cultural perspectives, and transcultural ideas (Cross et al. 1989). Ultimately, multicultural health encompasses various ways of thinking, being, and healing in a diverse world (Kleinman and Benson 2006). However, to understand the nuances of multicultural health, it is important to acknowledge what underlines "culture" (Echeverri et al. 2013). For instance, we must understand the visible and invisible constructs of culture. It is also important to address that culture is more than race or ethnicity (Echeverri et al. 2013). It encompasses deeper aspects of a person or community (Echeverri et al. 2013), such as demonstrated by the cultural iceberg structure (Table 1, Figure 1).

Table 1. Common Terms Associated with Multicultural Competency

\begin{tabular}{|l|l|}
\hline Term & \multicolumn{1}{|c|}{ Definition } \\
\hline Multicultural & "co-existence of diverse cultures..." (Chu 2005) \\
\hline Cultural Literacy & $\begin{array}{l}\text { "...developing new cultural literacies when you enter a new } \\
\text { culture, or interact with members of that culture" (Hirsch } \\
1983)\end{array}$ \\
\hline $\begin{array}{l}\text { Intercultural } \\
\text { Competence }\end{array}$ & $\begin{array}{l}\text { "...behavior and communication that are both effective and } \\
\text { appropriate in intercultural interactions" (Deardorff 2006 \& } \\
\text { 2012) }\end{array}$ \\
\hline Cross-cultural & "comparison of different cultures" (Schriefer 2017) \\
\hline Transcultural & "occurring in more than one culture" (Purnell 2012) \\
\hline
\end{tabular}

Figure 1. The Cultural Iceberg

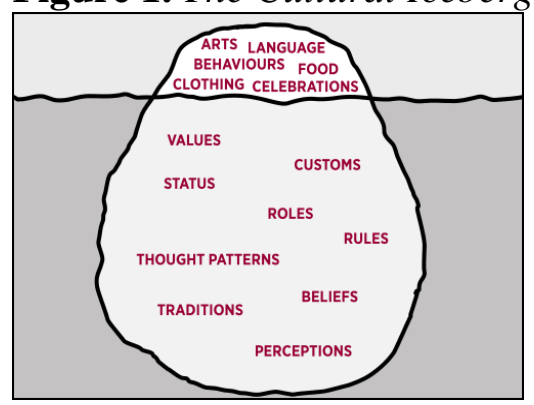

Source: Hirsch, 1983. 


\section{$\underline{\text { Migration and globalization }}$}

Some of the phenomena effecting multicultural health are migration and globalization. Globalization has impacted everything including law, policy, mobility, migration, health, education, and culture (Mok 2000). Globalization has many definitions, one of which is "the constant movements in international trade, economy, technology, and people" (Mok 2000). People often travel across borders either for emergency purposes or in search of new frontiers (Mok 2000). Some take their cultural traditions with them, yet, others completely adapt to new cultural phenomena, including new health practices. On the other hand, some people blend their traditional practices with those in their new life (Mok 2000).

According to culture analysis, globalization has its advantages and drawbacks; it also disrupts the status quo and creates more competition (Mok 2000). Advantages include an increased engagement with a variety of cultures, goods, and services (Hirst and Thompson 1995). A drawback is understanding that globalization may cause negative ripples for certain people and regions because of the lack of engagement with culturally literate professionals (Archibugi and Pietrobelli 2003). Moreover, many populations are experiencing atrocities like famine, poverty, slavery, and poor health with little understanding from their new places of residence (Archibugi and Pietrobelli 2003). The global health idea of "health for all" is truly impacted by globalization and the social determinants of health, which can be defined as a cross-national cultural movement (Huynen et al. 2005).

\section{$\underline{\text { Barriers between health professionals and patients }}$}

One of the ongoing trends when negotiating health is friction. According to Tsing, friction is defined as "producing movement, action, effect...always engaged... resistance..." (Tsing 2005). Health professionals have a job to do, which is to aid in the healing processes of their patients (Tsing 2005). Many patients want to ensure their cultures, traditions, and spiritual beliefs are a part of the healing process (Tsing 2005). This friction has caused many misunderstandings between health professionals and the cultural populations they work with. Trust has been lost, if gained at all. And too often, biases on both sides prevail as a result (Tsing 2005). Unfortunately, this can lead to both sides failing to progress in their quest for healing (Tsing 2005).

Another leading issue regarding multicultural health is the lack of adequate cultural training offered to health professionals. For instance, studies show that professionals lack many skills when working with refugees. Of those missing skills, the most reported include: social inclusion, interpersonal skills, cultural competency, intervention design, language acquisition, adequate knowledge about the refugee experience, as well as knowledge about global health and its related initiatives (Hill et al. 2009, Cheng et al. 2015, Lipson 1991, Drain et al. 2007). These trends appear in work with many other cultural populations as well as refugees. In order to train health education professionals with these skills, the Association of Refugee Health Coordinators recommend a holistic approach to 
training. ${ }^{6}$ Other studies mentioned having a designated platform for engaging health education professionals with these skills, such as universities (Ablah 2014).

Health professional bias has also been reported in recent years; and along with it, studies seeking to understand how bias develops in this field. According to a paper recently published by the Chronicle of Higher Education, bias comes in many forms including the belief in biased information, the entitlement bias, the reciprocity bias, the social-validation bias, and the moral-license bias (Lessig 2018). Pertinent to this literature and the promotion of cultural competency is the notion that health professionals may not realize the severity of their biases. Lessig continues to state how an individual's professional position blinds them of their bias because they truly believe they have done all the work they needed to understand any situation in their field, thus making them experts (Lessig 2018). While still striving to respect a health professionals' years of education and hard work, this belief can undermine work involving cultural competency.

\section{Frameworks supporting diplomacy in healthcare}

Research has shown that culture and diplomacy studies share common global goals (McDaniel et al. 2018, Gilboa 2001, Echeverri et al. 2013). Some of the familiar attributes include, communication, cultural literacy, negotiation skills, respect, and reaching a favorable outcome for everyone involved $\mathrm{McDaniel}$ et al. 2018, Gilboa 2001, Echeverri et al. 2013). Since multicultural health is a global issue, diplomacy skills would be beneficial in these healthcare settings. Likewise, proposing new frameworks has long been supported due to the changing nature of our world (Niknejad et al. 2016). The United Nations' 8 Millennium Development Goals (MDGs) in 2000 and the 17 Sustainable Development Goals (SDGs) for 2015 demonstrate the ongoing need to modify goals and frameworks as nations evolve over time. Specifically, the SDGs support global healthcare initiatives involving diplomacy skills with the third objective being "good health and wellbeing" for all. ${ }^{7}$

Frameworks for supporting multicultural healthcare include the Bray, Adamson, and Mason Cube, Arjun Appadurai's concept of "Scapes", and the Purnell Model for Cultural Competency. The Cube is used in comparative education to explain the different levels and dimensions of the educational world (Bray et al. 2014). In regards to multicultural health, the Cube displays Nonlocational Demographic Groups (Bray et al. 2014). Appadurai's "scapes" discusses the different, somewhat cultural landscapes, that shape the flows and frictions of globalization (Dimitriadis and Kamerelis 1997). Each of the five "scapes" can inform the flows of multicultural health competency, however the most relevant include Ethnoscape and Mediascape (Dimitriadis and Kamerelis 1997). Mediascape has afforded many populations a means to display their culture

\footnotetext{
${ }^{6}$ The Role of Refugee Health Coordinators (2018, January 18). Available at: https://www.acf.hhs. gov/orr/resource/the-role-of-refugee-health-coordinators.

${ }^{7}$ Sustainable Development Goals kick off with start of new year. United Nations website (2017, March 17). Available at: http://www.un.org/sustainabledevelopment/blog/2015/12/sustainabledevelopment-goals-kick-off-with-start-of-new-year/.
} 
across global technology and connect in real-time during crucial moments using platforms such as social media and the live internet (Dimitriadis and Kamerelis 1997). Whereas, Ethnoscape is in the form of the individual, physically moving across borders (Dimitriadis and Kamerelis 1997). Of the three frameworks, the Purnell Model for Cultural Competency includes guidelines for working with specific cultures and what we should know about them prior to providing care or education (Purnell 2012). Although the Purnell Model for Cultural Competency was developed for a healthcare setting, it can be used alongside other fields, such as diplomacy (Purnell 2012).

The Cube, the Purnell Model, and Appadurai's framework share similar characteristics for use in understanding multicultural paradigms. Additionally, components from each of the frameworks can be used to compare cultural health in the US and throughout the world.

\section{Methodology}

For the literature review, web searches were conducted between the years 1991 and 2018 in EbscoHost, MEDLINE, ERIC, PubMed, Academic Premiere, Google Scholar, and the Indiana University Libraries database. Keywords used as search terms included: multicultural health, refugee health, cultural health education, cultural health interventions, ministries of health, ministries of education, departments of education, competencies for health professionals, office of refugee resettlement, professional health education curriculum, cultural educational development, Bill and Melinda Gates Foundation, Clinton Foundation, Carter Foundation, UNICEF, WHO, UNESCO, World Bank, Millennium Development Goals, Sustainable Development Goals, Red Cross, and UN Refugee Agency. Specific journal searches include Journal of Immigrant and Minority Health; American Journal of Public Health; Health Education Journal; Journal of Community Health; Journal of Ethnicity and Health; International Journal of Public Health; International Journal of Health Sciences and Research; Journal of Social Work; Journal of General Practice; Ethnic Health; Qualitative Health Research; and the Journal of Curriculum Studies. In addition to journal and web sources, expert reports, books, and white papers were also consulted.

For the diplomacy skills models, web searches were conducted between the years 2001 and 2018 in EbscoHost, ERIC, PubMed, Academic Premiere, Google Scholar, and the Indiana University Libraries database. Keywords used as search terms included: diplomacy models, diplomacy skills, business diplomacy models, media diplomacy models, council on foreign relations, model diplomacy, health diplomacy models, department of state, diplomatic theory, principles of diplomacy, peace treaties, Foreign Service diplomacy models, the United Nations, WHO, UNESCO, World Bank, Millennium Development Goals, and the Sustainable Development Goals. Specific journal searches include Journal of Immigrant and Minority Health; Harvard Business Review; Harvard Law School; and Diplomacy and Statecraft. In addition to journal and web sources, expert reports, books, and white papers were also consulted. In addition to journal and 
web sources, colleagues who primarily work in international relations research were contacted for help in identifying current diplomatic training documents.

\section{Results of Current Diplomacy Model Search}

For the purpose of establishing a clear foundation, the results were organized first by including a prominent diplomacy skills model accompanied by a table of skills/characteristics, then by various industry diplomacy skills models also accompanied by skill/characteristics. Each document, was then compared to the original diplomacy skills training to determine which skills/characteristic were similar and which were added in the industry documents. This was to determine trends across industries and hopefully create a new adequate health professional diplomacy model. Tables and charts accompanied by summaries were developed to exhibit data.

\section{Foreign Service Diplomacy Framework/Model}

Title: Three Principles of Diplomacy

Summary: This framework is drawn from the experiences of Colin Powell and George Keenan, both political diplomats in their time. The main takeaway from this reading is that each component alone is sufficient, but only when they are combined, can they be a diplomatic force ${ }^{8}$ (Table 2).

Table 2. Diplomacy Components (Wilson Center 2018)

\begin{tabular}{|c|c|l|}
\hline & Component & \multicolumn{1}{c|}{ Description } \\
\hline 1 & Patience & $\begin{array}{l}\text { Is indispensable to long-term success in foreign } \\
\text { policy...Indeed, patience in a great power goes to the } \\
\text { core principle of diplomacy itself, one of three principles } \\
\text { that I would like to talk about this evening. }\end{array}$ \\
\hline 2 & Power & $\begin{array}{l}\text { Is necessary because it is not possible to reason with } \\
\text { every adversary that threatens a vital interest. }\end{array}$ \\
\hline 3 & Staying the Course & $\begin{array}{l}\text { Means that, "After the fighting stops, other hard work } \\
\text { begins, including political and diplomatic work, } \\
\text { rebuilding, transforming a defeated country". }\end{array}$ \\
\hline 4 & $\begin{array}{c}\text { Working with Rather } \\
\text { than Against }\end{array}$ & $\begin{array}{l}\text { A wise diplomacy magnifies power's attractive quality } \\
\text { by using power to benefit others as well as oneself. }\end{array}$ \\
\hline 5 & $\begin{array}{c}\text { Provide Honorable } \\
\text { Paths to Escape }\end{array}$ & $\begin{array}{l}\text { Adversary needs an honorable path of escape if we are } \\
\text { to achieve our main policy goals without using force. }\end{array}$ \\
\hline 6 & Persuasion & Evokes the first principle of diplomacy (Power). \\
\hline
\end{tabular}

${ }^{8}$ The Principles of Diplomacy (2018, October). Wilson Center. Available at: https://www.wilson center.org/publication/three-principles-diplomacy. 
Industry Specific Diplomacy Skills Models

\section{A. Business Diplomacy Model \#1}

Title: Business Diplomacy in International Firms

Summary: This model was developed to examine the influence of firm characteristics on business diplomacy policies with employees. Although the findings were quantitative, the insight proved fruitful. The main takeaway from this study is that employees in the firm believed business diplomacy initiatives should be shared throughout the entire company, not just with top stakeholders. As a business model, the components represent the factors associated with preparing employees with robust knowledge of their business diplomacy department (Betlem 2012, Figure 2, Table 3).

\section{Figure 2. Business Diplomacy Framework}

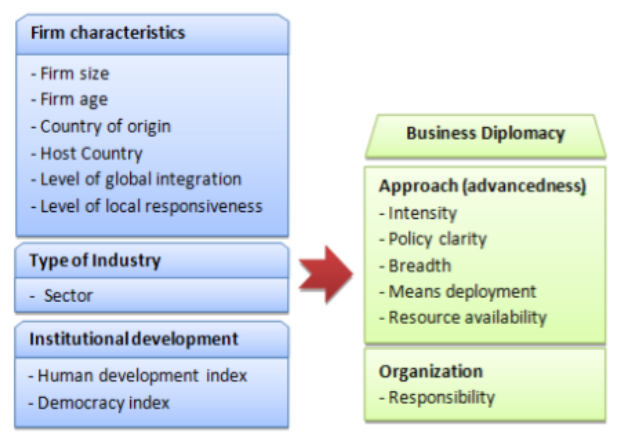

Source: Betlem, 2012.

Table 3. Business Diplomacy Components (Betlem 2012)

\begin{tabular}{|c|c|l|}
\hline & Component & \multicolumn{1}{c|}{ Description } \\
\hline 1 & Intensity & $\begin{array}{l}\text { Reflects the extent to which a company actively establishes and } \\
\text { sustains positive relationships with FGreps and NONg stakeholders. }\end{array}$ \\
\hline 2 & Policy Clarity & $\begin{array}{l}\text { Reflects the extent to which a MNC has a clear and organization- } \\
\text { wide policy on how to establish and sustain these relationships. }\end{array}$ \\
\hline 3 & Breadth & $\begin{array}{l}\text { Reflects the extent to which establishing and sustaining these } \\
\text { relationships is done by every company representative. }\end{array}$ \\
\hline 4 & $\begin{array}{c}\text { Means } \\
\text { Deployment }\end{array}$ & $\begin{array}{l}\text { Reflects the extent to which the company deploys a diversity of } \\
\text { means for establishing and sustaining positive relationships with } \\
\text { FGreps and NONg stakeholders. }\end{array}$ \\
\hline 5 & $\begin{array}{l}\text { Resource } \\
\text { Availability }\end{array}$ & $\begin{array}{l}\text { Reflects the extent to which the company uses multiple firm } \\
\text { resources (e.g. financial, time, knowledge) to establish and sustain } \\
\text { these relationships. }\end{array}$ \\
\hline 6 & $\begin{array}{l}\text { Reflects the extent to which the company's responsibility for } \\
\text { establishing and sustaining positive relationships with FGreps and } \\
\text { RONg stakeholders lies on the headquarters level or within the } \\
\text { foreign subsidiaries, or whether they are both partly responsible. }\end{array}$ \\
\hline
\end{tabular}




\section{B. Business Diplomacy Model \#2}

Title: Lessons from Business Negotiators: Negotiation Techniques from International Diplomacy

Summary: This list of essential diplomacy skills discusses what it means to succeed in negotiations and to retain relationships as well. This framework is used to teach Americans how to sustain relationships with other cultures while doing business. Ultimately, this tool is useful for ongoing positive cultural relationships in business ${ }^{9}$ (Table 4 ).

Table 4. Business Diplomacy Components (HLR 2018)

\begin{tabular}{|c|c|l|}
\hline & Component & \multicolumn{1}{c|}{ Description } \\
\hline 1 & $\begin{array}{c}\text { Negotiate } \\
\text { Continuously }\end{array}$ & $\begin{array}{l}\text { Who must apply their agreement to unforeseen circumstances and } \\
\text { adjust their relationship to a constantly changing environment. }\end{array}$ \\
\hline 2 & $\begin{array}{c}\text { Seek to } \\
\text { Harmonize }\end{array}$ & $\begin{array}{l}\text { Diplomats know that the key to building relationships lies in } \\
\text { understanding other countries' concerns and priorities. }\end{array}$ \\
\hline 3 & $\begin{array}{c}\text { Patience of a } \\
\text { Clockmaker }\end{array}$ & $\begin{array}{l}\text { Time is indeed money, but scrimping on time during a negotiation } \\
\text { may result in an undercapitalized deal. Whether time, money, or } \\
\text { both are in short supply, undercapitalization can be the kiss of death } \\
\text { for any contract. }\end{array}$ \\
\hline 4 & $\begin{array}{c}\text { Saturate Your } \\
\text { Mind }\end{array}$ & $\begin{array}{l}\text { Explore virtually every dimension of the organizations, countries, } \\
\text { and people with whom they were to come into contact. }\end{array}$ \\
\hline 5 & Apt Listeners & $\begin{array}{l}\text { Successful negotiation requires vigilance about your own words and } \\
\text { behavior as well as a keen observation of the other party. }\end{array}$ \\
\hline 6 & Show Respect & $\begin{array}{l}\text { Diplomacy's rituals and formalities, which acknowledge another } \\
\text { country's sovereign status, can be effective in signaling respect and } \\
\text { deference in corporate negotiations. }\end{array}$ \\
\hline
\end{tabular}

\section{Media Diplomacy Model}

Title: Diplomacy in the Media Age

Summary: This framework is taken from a study examining three conceptual media diplomacy models. Media is highlighted as a central component to delivering foreign policy information to the world and influence public opinion, yet, each aims to promote conflict resolution. This model did not reveal actual definitions for the components. Instead, the components represented a list the actors and conditions fostered in media diplomacy (Gilboa 2001). However, including this framework was essential to understanding how diplomacy fits into other sectors besides Foreign Service or industries somewhat affiliated with Foreign Service (Figure 3, Table 5).

\footnotetext{
${ }^{9}$ Lessons for Business Negotiators: Negotiation Techniques from International Diplomacy (2018, July 16). Harvard Law Review. Available at: https://www.pon.harvard.edu/daily/dealmaking-daily/ the-art-of-deal-diplomacy/.
} 
Figure 3. Media Diplomacy Comparison Chart

\begin{tabular}{|l|c|c|c|}
\hline Attribute & Public Diplomacy & Media Diplomacy & $\begin{array}{c}\text { Media-Broker } \\
\text { Diplomacy }\end{array}$ \\
\hline Context & Confrontation & Conflict resolution & Negotiations \\
\hline Initiators & Officials & Officials & Journalists \\
\hline Time frame & Long range & Short range & Immediate \\
\hline Goals & General & Specific & Very specific \\
\hline Method & $\begin{array}{c}\text { Promote } \\
\text { favourable image }\end{array}$ & $\begin{array}{c}\text { Appeal for conflict } \\
\text { resolution }\end{array}$ & Mediation \\
\hline Sides & One sided & Joint & All sides \\
\hline Target & Foreign societies & $\begin{array}{c}\text { Domestic/foreign } \\
\text { societies }\end{array}$ & Officials/public opinion \\
\hline Medium & Multiple channels & Mass Media & Mass Media \\
\hline
\end{tabular}

Source: Gilboa, 2001.

Table 5. Media Diplomacy Components (Gilboa 2001)

\begin{tabular}{|l|c|}
\hline & Component \\
\hline 1 & Conflict Resolution \\
\hline 2 & Officials \\
\hline 3 & Short Range \\
\hline 4 & Specific \\
\hline 5 & Appeal or Conflict Resolution \\
\hline 6 & Joint \\
\hline 7 & Domestic Foreign/societies \\
\hline 8 & Mass Media \\
\hline
\end{tabular}

\section{Health Diplomacy Model \#1}

Title: Diplomacy Needs Action

Summary: This framework is a part of an international health diplomacy training program. This program trains students, executives, and intermediates for a fee of approximately $\$ 800$ US dollars. It is a 3 to 5 day intensive training program on global health and diplomatic practice. As this is a closed course, no descriptions for their suggested framework components were available during the research period. ${ }^{10}$ However, including these components proved useful in understanding how global heath and diplomacy are being taught internationally (Table 6).

Table 6. Health Diplomacy Components (GHD ID 2018)

\begin{tabular}{|c|c|}
\hline & Component \\
\hline 1 & Negotiation Manner and Strategy \\
\hline 2 & Social Influencing \\
\hline 3 & Building Professional Image \\
\hline 4 & Influencing People \\
\hline 5 & Collaboration \\
\hline 6 & Decision Making \\
\hline
\end{tabular}

\footnotetext{
${ }^{10}$ Diplomacy Needs Action (2018, October). Global Health Diplomacy. Available at: http://global healthdiplomacy.id/index.php\#contentExecutive.
} 


\section{E. Health Diplomacy Model \#2}

Title: Negotiating for Doctors/Hospitals

Summary: This framework set in the setting of doctor/patient relationships deals with attempting health negotiations in order for both parties to come to a favorable agreement. This framework highlights the understanding of additional perspectives not present at the negotiation table and aims to keep the discussion focused on the outcome. This is different than the other frameworks because it stresses external stakeholders and perspectives versus zoning in on only what the person in "front of you" wants in the negotiation ${ }^{11}$ (Table 7).

Table 7. Health Diplomacy Components (HBR 2013)

\begin{tabular}{|c|c|c|}
\hline & Component & Description \\
\hline 1 & $\begin{array}{c}\text { Focus on } \\
\text { Interests, Not } \\
\text { Positions }\end{array}$ & $\begin{array}{l}\text { Too often, health professionals fall into the trap of thinking that } \\
\text { there is one correct answer (solution, diagnosis, prescription), } \\
\text { and that it will win the day; but human interactions are more } \\
\text { complicated than that. }\end{array}$ \\
\hline 2 & Framin & It's not just what you say, it’s how you say it. \\
\hline 3 & $\begin{array}{l}\text { Negotiation } \\
\text { Space }\end{array}$ & $\begin{array}{l}\text { Keep an eye on all of the parties that are relevant to this } \\
\text { negotiation, not just those who are at the table. }\end{array}$ \\
\hline
\end{tabular}

\section{Discussion}

The models presented in this paper demonstrated a breadth of diplomacy initiatives across sectors. They were clear in revealing the objectives of the frameworks and how it should be used in the associated fields. In comparison with the Foreign Service framework (Model A), the subsequent models focused less on power moves and more on people, space, and ongoing relationships.

In line with the original diplomacy skills model, each model emphasized the need for both parties in the negotiation to have a favorable outcome. The idea of patience was a theme throughout the models as well. Persuasion, although mentioned under different terminology, was a key component for the models. In fact, persuasion and patience came hand in hand when demonstrating the ongoing relationship aspect of diplomacy.

The models displayed differences as well as similarities. Some provided matching diagrams for visual learners, while others told stories to frame their components. Other models became difficult to pin down definitions for their components, if there were definitions at all. However, all models were theoretical in nature. As a result, there were no assessments connected to the models. Therefore, readers were unable to see the long-term benefits of implementing diplomacy training in specific fields. Additionally, the use of simulation training

\footnotetext{
${ }^{11}$ Negotiation Strategies for Doctors - Hospitals (2013, October 21). Harvard Business Review. Available at: https://hbr.org/2013/10/negotiation-strategies-for-doctors-and-hospitals.
} 
was mentioned in order to provide learners with diplomacy practice before entering the field.

Whether it was the business idea of a bottom line, diplomats upholding nations, media representing political life, or health care professionals healing a life; the models represented an overall respect for negotiating on an even playing field of understanding and care. Moving forward, each model has reliable contributions to the development of new frameworks. In regards to multicultural health, the current components can be built upon by adding specific health and culture aspects as well as a simulation assessment piece. The next step will be to develop a new multicultural health diplomacy model by combining the most pertinent components found from existing diplomacy models, global culture frameworks, and specific health negotiation needs.

\section{Health Diplomacy Model Proposal}

After analyzing the results from current diplomacy models. A new model was developed to help prepare health professionals for interacting effectively with different cultural populations. This model comes with a diagram, a chart of skills/characteristics with descriptions, and a summary of intended use.

\section{Multicultural Health Diplomacy: A Model for Training Health Professionals Interacting with Different Cultures}

Multicultural Health Diplomacy (MHD) is a proposed model for the purpose of training health professionals with a set of skills suitable for engaging in transcultural healthcare. Fundamental to health education and healthcare services, these skills can serve as a model to create a healthcare system which supports the diversity and well-being of all individuals. Multicultural Health Diplomacy is inspired from Global Health Diplomacy, which has its foundation in foreign policy. Therefore, using these skills at the community level can also serve as a conduit for bridging ground level healthcare to foreign policy. This model endorses actors such as health professionals, health educators, and patients. This new model is unique for its promotion of combining knowledge, skills, and assessments for global health practices. The skills in this model can be used across cultures and contexts. The knowledge provides a foundation that can be built upon for each specific, cultural setting. Finally, the assessments allow professionals to reflect on their practices. As a diplomatic foundation, MHD promotes the benefit of all individuals involved in the health negotiation process. Meaning, this training promotes the idea of a collaborative space in which all parties come out with a favorable outcome (Figure 4, Table 8). 
Figure 4. MHD Components Diagram

\begin{tabular}{|c|c|c|}
\hline $\begin{array}{c}\text { 1. Effective } \\
\text { Communication }\end{array}$ & 2. Health Negotiation & 3. Precision \\
\hline $\begin{array}{c}\text { 4. Health Literacy \& } \\
\text { Competency }\end{array}$ & $\begin{array}{c}\text { Multicultural Health } \\
\text { Diplomacy Model }\end{array}$ & $\begin{array}{c}\text { 5. Cultural Literacy \& } \\
\text { Competency }\end{array}$ \\
\hline $\begin{array}{c}\text { 6. Ongoing } \\
\text { Collaboration }\end{array}$ & $\begin{array}{c}\text { 7. Patience and } \\
\text { Respect }\end{array}$ & $\begin{array}{c}\text { 8. Health Professional } \\
\text { Responsibility }\end{array}$ \\
\hline
\end{tabular}

Source: Original Diagram.

Table 8. MHD Components and Descriptions

\begin{tabular}{|c|c|c|c|}
\hline & Component & Description & Assessment \\
\hline 1 & $\begin{array}{c}\text { Effective } \\
\text { Communication }\end{array}$ & $\begin{array}{l}\text { Communication between two or } \\
\text { more persons wherein the } \\
\text { intended message is successfully } \\
\text { delivered, received and } \\
\text { understood } \\
\text { (Business Jargons 2018). }\end{array}$ & Simulation Scenarios \\
\hline 2 & $\begin{array}{c}\text { Health } \\
\text { Negotiation }\end{array}$ & $\begin{array}{l}\text { Health discussions for the } \\
\text { purpose of reaching an } \\
\text { agreement on health services, } \\
\text { needs, prevention, and } \\
\text { treatment. }\end{array}$ & Simulation Scenarios \\
\hline 3 & Precision & $\begin{array}{l}\text { The ability to solve core health } \\
\text { problems specific to certain } \\
\text { individuals or cultural } \\
\text { populations. }\end{array}$ & $\begin{array}{l}\text { Evident by patient reporting } \\
\text { satisfaction after interacting with } \\
\text { health professional. Evident by } \\
\text { reports of increased positive health } \\
\text { outcomes after interacting with } \\
\text { patients. Possibly a survey. }\end{array}$ \\
\hline 4 & $\begin{array}{l}\text { Health Literacy } \\
\text { \& Competency }\end{array}$ & $\begin{array}{l}\text { Developing new health literacies } \\
\text { upon entering a new culture. } \\
\text { Then, demonstrating this } \\
\text { knowledge during interactions } \\
\text { with those cultures. }\end{array}$ & $\begin{array}{l}\text { Developing thorough briefs or } \\
\text { reports on cultures prior to } \\
\text { interaction. Then, evidence of } \\
\text { competency in the field. }\end{array}$ \\
\hline 5 & $\begin{array}{l}\text { Cultural Literacy } \\
\& \text { Competency }\end{array}$ & $\begin{array}{l}\text { Developing new cultural } \\
\text { literacies upon entering a new } \\
\text { culture. Then, demonstrating } \\
\text { this knowledge during } \\
\text { interactions with those cultures. }\end{array}$ & $\begin{array}{l}\text { Developing thorough briefs or } \\
\text { reports on cultures prior to } \\
\text { interaction. Then, evidence of } \\
\text { competency in the field. }\end{array}$ \\
\hline 6 & $\begin{array}{c}\text { Ongoing } \\
\text { Collaboration }\end{array}$ & $\begin{array}{l}\text { Establishing rapport and } \\
\text { sustaining health } \\
\text { professional/patient } \\
\text { relationships for further support } \\
\text { in positive and long-term health } \\
\text { outcomes. }\end{array}$ & $\begin{array}{c}\text { A record of an ongoing } \\
\text { communication between health } \\
\text { professional and patient. An } \\
\text { established system allowing patients } \\
\text { opportunities to contribute on } \\
\text { knowledge regarding their cultures } \\
\text { health beliefs and traditions. }\end{array}$ \\
\hline 7 & $\begin{array}{l}\text { Patience and } \\
\text { Respect }\end{array}$ & $\begin{array}{l}\text { Demonstrating unbiased } \\
\text { empathy, compassion, and } \\
\text { civility during interactions with } \\
\text { other cultures. }\end{array}$ & $\begin{array}{c}\text { Evident by patient reporting } \\
\text { satisfaction after interacting with } \\
\text { health professional. Possibly a } \\
\text { survey. }\end{array}$ \\
\hline 8 & $\begin{array}{c}\text { Health } \\
\text { Professional } \\
\text { Responsibility }\end{array}$ & $\begin{array}{l}\text { Constant self-reflection and bias } \\
\text { monitoring regarding job } \\
\text { purpose, goals, and continued } \\
\text { education throughout the } \\
\text { healthcare process. }\end{array}$ & $\begin{array}{l}\text { Ongoing completion of continued } \\
\text { education and professional } \\
\text { development. }\end{array}$ \\
\hline
\end{tabular}




\section{Component Summary and Rationale}

The list of components was chosen after careful research regarding the needs of health professionals working with cultural populations. Specifically, components were adapted from or added to information found in the literature review as well as current models and frameworks. For instance, MHD incorporates suggestions from other ideas adopted from the Purnell Model. In this case, cultural literacy and health literacy are identified. As in many industries, this model is on trend with diplomacy and healthcare. This model also bodes well for positive future implications such as increased health outcomes and behaviors around the world for both professionals and patients. The model can easily be modified for specific cultures and can also be adapted for use in interactive learning. For instance, professionals will be able to click on each component in the diagram to reveal the definitions and simulation scenarios. This serves as another attribute for holistic application of the components.

\section{Conclusion}

The benefits of establishing a specific model for health professionals include preparing field ready professionals, adapting to evolving global healthcare, and supporting specific cultural needs in various communities. As a basic starting point, a health professional model will be useful for current trends in healthcare involving migrating populations, such as immigrants and refugees. As a growing population comprised of many cultures, professionals need resources they can be quickly trained on and referenced to address refugee health issues. An implicit understanding across each of the previous diplomacy models is that individuals need to become literate about the cultures they constantly interact with and demonstrate ongoing competence. Therefore, the new health professional model explicitly states this need. Ultimately, laying the groundwork for a new model demonstrates support of our health professionals and the populations we hope to serve. Incorporating diplomacy in multicultural health demonstrates care for authentic learning and collaboration for optimal global health outcomes.

\section{Acknowledgements}

My thanks to Larry D. Purnell, Mark Bray, Bob Adamson, Mark Mason, and Arjun Appadurai for allowing me to draw from concepts, templates, frameworks, and models they have developed. My thanks to Dr. Hilary Kahn, Dr. Andrea Siqueira, Dr. David K. Lohrmann, and Indiana University for assisting me with guidance and the resources needed to complete this paper. 


\section{References}

Ablah E, Biberman D, Weist E, Buekens P, Bentley M, Burke D, et al. (2014) Improving Global Health Education: Development of a Global Health Competency Model. American Journal of Tropical Medicine Hygiene 90(3): 560-565.

Archibugi D, Pietrobelli C (2003) The Globalisation of Technology and its Implications for Developing Countries: Windows of Opportunity or Further Burden? Technological Forecasting and Social Change 70(9): 861-883.

Betlem F (2012) Business Diplomacy in International Firms: An Extensive Literature Review and Results form a Survey. School of Management and Governance, University of Twente.

Bray M, Adamson B, Mason M (Eds.) (2014) Comparative Education Research: Approaches and Methods ( $2^{\text {nd }}$ ed.). Hong Kong, China: Comparative Education Research Centre, The University of Hong Kong and Springer.

Cheng I, Drillich A, Schattner P (2015) Refugee Experiences of General Practice in Countries of Resettlement: A Literature Review. British Journal of General Practice 65(632): 171-176.

Chu CM (2005, March 18) Multiculturalism. International Federation of Library Associations. Available at: https://www.ifla.org/publications/defining-multiculturalism.

Cross T, Bazron B, Dennis K, Isaacs M (1989) Towards a Culturally Competent System of Care, Volume I. Washington, DC: CAASP Technical Assistance Center, Georgetown University Child Development Center.

Cullen L, Adams S (2012) Planning for Implementation of Evidence-based Practice. Journal of Nursing Administration 42(4): 220-230.

Deardorff DK (2012) Framework: Intercultural Competence Model. In: K Berardo, DK Deardorff (Eds.), Building Cultural Competence: Innovative Activities and Models. Sterling Virginia: Stylus Publishing.

Deardorff DK (2006) The Identification and Assessment of Intercultural Competence as a Student Outcome of Internationalization at Institutions of Higher Education in the United States. Journal of Studies in International Education 10: 241-266

Dimitriadis G, Kamerelis G (1997) Shifting Terrains: Mapping Education within a Global Landscape. Annals of the American Academy of Political and Social Science 551: 137-150.

Drain P, Primak A, Hunt D, Fawzi W, Holmes K, Gardner P (2007) Global Health in Medical Education: A Call for more Training and Opportunities. Academic Medicine 82(3): 226-230.

Echeverri M, Brookover C, Kennedy K (2013) Assessing pharmacy students' selfperception of Cultural Competence. Journal of Health Care for the Poor and Underserved 24(1): 64-92.

Gilboa E (2001) Diplomacy in the Media Age: Three Models of uses and Effects. Diplomacy and Statecraft 12(2): 1-28.

Hill L, Gray R, Stroud J, Chiripanyanga S (2009) Inter-professional Learning to Prepare Medical and Social Work Students for Practice with Refugees and Asylum Seekers. Journal of Social Work Education 28(3): 298-308.

Hirsch E (1983) Cultural literacy. The American Scholar 52(2): 159-169.

Hirst P, Thompson G (1995) Globalization and the Future of the Nation State. Economy and Society 24(3): 408-442.

Huynen M, Martens P, Hilderink K (2005) The Health Impacts of Globalization: A Conceptual Framework. Globalization and Health 1(14): 1-12. 
Kleinman A, Benson P (2006) Anthropology in the Clinic: The Problem of Cultural Competency and how to fix It. PLoS Me 3(10): e294. Retrieved from: https://doi.org/ 10.1371/journal.pmed.0030294.

Lessig L (2018) The Chronicle Review: How Academic Corruption Works. The Chronicle of Higher Education 65(8): 6-11.

Lipson G (1991) Afghan Refugee Health: Some Findings and Suggestions. Qualitative Health Research 1(3): 349-369.

McDaniel M, Sprout E, Boudreau D, Turgeon A (2018) Diplomacy. National Geographic. Available at: https://www.nationalgeographic.org/encyclopedia/diplomacy/.

Mok KH (2000) Impact of Globalization: A Study of Quality Assurance Systems of Higher Education in Hong Kong and Singapore. Comparative Education Review 44(2): 148-174.

Niknejad N, Ghani I, Hussin A, Saedi A (2016) Proposing a New Framework for Service Oriented Architecture Adoption. $3^{\text {rd }}$ International Conference on Computer and Information Sciences. Kuala Lumpur Convention Centre, 15-17 August 2016. Malaysia Johor, Malaysia.

Nyatanga B (2001) Celebrating Cultural Diversity. International Journal of Palliative Nursing 7(2).

Purnell LD (2012) Transcultural Health Care: A Culturally Competent Approach (4 $4^{\text {th }}$ ed.). New York: F.A. Davis Company.

Schriefer P (2017, November 30). What's the Difference between Multicultural, Intercultural, and Cross-cultural Communication? Spring Institute for Intercultural Learning. Available at: https://www.springinstitute.org/whats-difference-multicultural-intercul tural-cross-cultural-com-munication/.

The Royal Australian College of General Practitioners (2011) Multicultural Health: Definition. Available at: https://curriculum.racgp.org.au/statements/multicultural-health/.

Tsing A (2005) Friction: An Ethnography of Global Connections. Princeton University Press.

Walsh K (2017) Cultural Competence could be the key to your Workplace Success or Failure. Bentley University Press. 